

Article history :

Received : 16.04.2016

Revised : 25.04.2016

Accepted : 05.05.2016

Members of the Research Forum

Associated Authors:

${ }^{1}$ Department of Horticulture, College

of Agriculture, Junagadh

Agricultural University, JUNAGADH

(GUJARAT) INDIA

${ }^{2}$ Department of Agricultural Extension, Junagadh Agricultural University, JUNAGADH (GUJARAT) INDIA

Author for correspondence : POOJA MAHETA

Department of Horticulture, College of Agriculture, Junagadh

Agricultural University, JUNAGADH (GUJARAT) INDIA

Email : mahetapooja11@gmail.com
THEASIAN JOURNALOF HORTICULTURE

Volume 11 | Issue 1 | June, 2016 | 132-135

Visit us -www.researchjournal.co.in

TA'

S.

DOI : 10.15740/HAS/TAJH/11.1/132-135

\title{
Effect of nitrogen and phosphorus on growth, flowering and flower yield of China aster (Callistephus chinensis L. Nees) cv. POORNIMA
}

\section{POOJA MAHETA, N.D. POLARA ${ }^{1}$ AND JYOTIKA RATHOD ${ }^{2}$}

ABSTRACT : The present investigation was carried out at Horticulture Research Station, Jambavadi Farm, Junagadh Agricultural University, Junagadh (Gujarat) during October 2014 to March 2015. The experiment was laid out in Factorial Randomized Block Design. The treatments comprised of two factors (1) nitrogen with four level viz., $150 \mathrm{~kg} \mathrm{~N} \mathrm{ha}^{-1}\left(\mathrm{~N}_{1}\right), 200 \mathrm{~kg} \mathrm{~N} \mathrm{ha}^{-1}\left(\mathrm{~N}_{2}\right)$, $250 \mathrm{~kg} \mathrm{~N} \mathrm{ha}^{-1}\left(\mathrm{~N}_{3}\right), 300 \mathrm{~kg} \mathrm{Nha}^{-1}\left(\mathrm{~N}_{4}\right)$ and three levels of phosphorus i.e. $100 \mathrm{~kg} \mathrm{P}_{2} \mathrm{O}_{5} \mathrm{ha}^{-1}\left(\mathrm{P}_{1}\right), 150$ $\mathrm{kg} \mathrm{P}_{2} \mathrm{O}_{5}$ ha $^{-1}\left(\mathrm{P}_{2}\right), 200 \mathrm{~kg} \mathrm{P}_{2} \mathrm{O}_{5}$ ha $^{-1}\left(\mathrm{P}_{3}\right)$ with three replications. Both the highest levels of $\mathrm{N}$ and $\mathrm{P}$ significantly improved growth parameters i.e. plant height $(51.56 \mathrm{~cm})$, plant spread $\left(328.67 \mathrm{~cm}^{2}\right)$, secondary branches per plant (17.67), fresh weight (137.22 g) and dry weight $(69.78 \mathrm{~g})$ in treatment $\mathrm{N}_{4}\left(300 \mathrm{~kg} \mathrm{~N} \mathrm{ha}^{-1}\right)$ whereas, in case of phosphorus the plant height $(47.08 \mathrm{~cm})$, plant spread $\left(316.00 \mathrm{~cm}^{2}\right)$, number of branches per plant (16.92), fresh weight (132.00 $\left.\mathrm{g}\right)$ and dry weight (72 g) was noted in treatment $\mathrm{P}_{3}\left(200 \mathrm{~kg} \mathrm{P}_{2} \mathrm{O}_{5} \mathrm{~kg} \mathrm{ha}^{-1}\right)$. Maximum flowering span (79.11 days), number of flowers per plant (24.78) and yield of flowers (22.67 $\left.\mathrm{t} \mathrm{ha}^{-1}\right)$ were registered in $300 \mathrm{~kg} \mathrm{~N} \mathrm{ha}^{-1}$ treatment. Similarly, maximum flowering span (71.58 days), number of flowers per plant (23.58) and yield of flowers $\left(22.08 \mathrm{tha}^{-1}\right)$ were registered in $\mathrm{P}_{3}\left(200 \mathrm{~kg} \mathrm{P} \mathrm{ha}^{-1}\right)$. Thus, cultivation of China aster in medium black soil, the fertilizer application at the rate of $300 \mathrm{~kg} \mathrm{~N}$ $\mathrm{ha}^{-1}$ in two splits (first half as basal application and remaining half at 30 days after transplanting) and $200 \mathrm{~kg} \mathrm{P}_{2} \mathrm{O}_{5} \mathrm{ha}^{-1}$ as basal dose has been found the best.

KEY WORDS : China aster, cv. POORNIMA, Nitrogen, Phosphorus

HOW TO CITE THIS ARTICLE : Maheta, Pooja, Polara, N.D. and Rathod, Jyotika (2016). Effect of nitrogen and phosphorus on growth, flowering and flower yield of China aster (Callistephus chinensis L. Nees) cv. POORNIMA. Asian J. Hort., 11(1) : 132-135, DOI : 10.15740/HAS/TAJH/11.1/132-135. 